\title{
Trophic status and its regulating factor determination at the Rewalsar Lake, northwest Himalaya (HP), India, based on selected parameters and multivariate statistical analysis
}

\author{
Pawan Kumar $^{1} \cdot$ Ambrish Kumar Mahajan ${ }^{1}$
}

Received: 13 March 2020 / Accepted: 16 June 2020 / Published online: 22 June 2020

(c) Springer Nature Switzerland AG 2020

\begin{abstract}
The present study at Rewalsar Lake demonstrates trophic status and its regulating factor based on the selected physiochemical parameters and multivariate statistical analysis. The chlorophyll-a in the lake was found to be $15.85 \pm 4.16 \mathrm{mg}$ $\mathrm{L}^{-1}$, whereas total phosphorus as $0.21 \pm 0.11 \mathrm{mg} \mathrm{L}^{-1}$. Secchi disk indicated low visibility $(0.57 \pm 0.01 \mathrm{~m})$ in the lake that may be due to increased turbidity, phytoplankton, organic color and other suspended particles. The value of trophic state index (TSI) determined in the range of 78.76-87.89 (avg. 83.62 \pm 3.09 ) specified that the Rewalsar Lake is hyper-eutrophic in status. The scatter plot of TSI(Chl-a)-TSI(SD) and TSI(Chl-a)-TSI(TP) revealed the increased nutrient (TP) as a main regulating factor for the higher value of TSI in the lake. The presence of $\mathrm{NO}_{3}^{-}\left(6.97 \pm 1.56 \mathrm{mg} \mathrm{L}^{-1}\right)$ and $\mathrm{NH}_{4}^{+}(18.93 \pm 5.02 \mathrm{mg}$ $\mathrm{L}^{-1}$ ) in the lake may be owing to the use of nitrogenous fertilizers in the surrounding region and entry of other organic substances. Instead, these compounds may also be associated with the natural processes, like as the nitrification and ammonification. The principal component analysis from the data set of 12 variables indicated a total of $59.69 \%$ variance, i.e., PC1-27.35, PC2-17.48 and PC3-14.67\%. The study further confirmed that the Rewalsar Lake is mainly influenced by the natural sources, whereas the regulating factor for the trophic status via anthropogenic activities. The water sampling sites in the lake are found to be grouped among various clusters and showed the spatial variability of different parameters.
\end{abstract}

Keywords Chlorophyll-a · Hyper-eutrophic · Nutrient enrichment · Principal component analysis · Regulating factors . Trophic state index

\section{Introduction}

The lakes are a major source of freshwater all over the world, but the nutrient enrichment and bacterial contamination have deteriorated their water quality at a large scale $[1,2]$. Changing quality has created the water scarcity and a huge mass of population thus been deprived from using the freshwater for various purposes [3, 4]. However, the obnoxious materials that stay in water bodies for a longtime period bring changes in the physiochemical characteristics as well as the natural scenario of the lakes [5]. The Himalayan lakes are under stress due to mismanaged human activities, which increase nutrients and pollution in terms of heavy metals toxicity and bacterial contamination [6-8]. The management and preservation of the lakes at present have become a great challenge for environmentalists and managers $[5,9]$.

The eutrophication is also a main problem of the freshwater lakes, and it is specified for the lakes having nutrient enrichment. It causes excessive growth of algae and is considered to be responsible for degrading the qualitative nature of the lakes $[5,10]$. The eutrophication is followed by the algal bloom, which generates toxin, worsens water quality, depletes dissolved oxygen (DO)

Pawan Kumar, pawan.evs@gmail.com| 'Department of Environmental Sciences, Central University of Himachal Pradesh, Dharamshala 176215, India. 
and decreases stability as well as diversity of the aquatic species [11]. The algae in water uses chlorophyll-a (Chla) for photosynthesis and is used to monitor nutrient status of the lakes. The phosphorus in lakes is proved as a primary factor for increasing productivity [12], and the main source of phosphorus is the use of chemical fertilizers.

The concentration of phosphorus in the lake depends on strength and duration of phosphorus release from the lake sediments. Hence, to decline eutrophication, it is essential to inactivate phosphorus release from the bottom sediments [13]. Algae and other phytoplankton are known to decrease visibility in the lakes; moreover, the transparency can also be influenced by organic color produced from the degradation of organic materials [14]. The trophic state index (TSI) is used to understand the eutrophic status of the lakes and can be observed with several methods including the Carlson's index $[10,15]$. The total phosphorus (TP), chlorophyll-a (Chl-a) and Secchi disk (SD) transparency are required for the Carlson's index and to understand nutrient status of water bodies [5]. Further, the satellite imageries are also being used these days to estimate the trophic state index as well as eutrophic status of the lakes $[16,17]$.

The total phosphorus determines the nutrient availability and chlorophyll-a represents the biomass, whereas the Secchi disk transparency measures the visibility in the lake, which is generally affected by the algae, macrophytes and organic color. It has been inferred by Carlson [18] as if TSI(SD) and TSI(Chl-a) are equal, then the light penetration is decreased due to the presence of algae, whereas if $\mathrm{TSI}(\mathrm{Chl}-\mathrm{a})<\mathrm{TSI}(\mathrm{SD})$, then the transparency is affected by the non-algal particles [19]. Apart from this, the TSI(Chla) $\geq T S I$ (TP) marks that the nutrient enrichment (TP) plays an important role behind growth of algae in the lakes. However, the TSI(Chl-a) <TSI(TP) infers lesser growth of algae as compared to the TP availability, thereby suggesting the influence of other sources $[5,19,20]$.

Although, Edmondson [21] and Carlson [18] had further inferred that the TSI(Chl-a) $<$ TSI(SD) in the highly nutritious lakes may be due to the presence of pico-plankton having more surface area per unit biomass of small cells as compared to micro-plankton and reduce more light [19]. The lakes from different parts of the world have been monitored for trophic status by several researchers in past and found to be eutrophic and hyper-eutrophic [22-27]. Indiscriminate constructions and tourists' actions for entertainment and religiousness at the Rewalsar Lake have deteriorated its water quality and increased the sedimentation rate $[2,28]$. An earlier study at this lake has shown the diurnal variations of phytoplankton (Euglenophyceae, Chlorophyceae, Cryptophyceae, Bacillariophyceae and Cyanophyceae) and zooplankton species (Cladocera, Copepoda and Rotifera) [29].

The Rewalsar Lake from a long time has been huge source of freshwater for drinking and agricultural purposes, but the drastic changes in the water quality have compelled local people to look for the alternate options, mainly the groundwater. However, installing pumps to utilize groundwater is very expensive owing to hard regional lithology and far from the reach of common man. A problem of fish kills repeatedly during summer season is also prevalent at this lake; instead, the polluted nature of lake also despairs the tourists visiting for entertainment and religious purposes. Thus, the Rewalsar Lake requires a detailed study for protection and improvement; therefore, the main objective of present study is to determine the trophic status and its regulating factors based on some physiochemical parameters and multivariate statistical analysis.

\section{Materials and methods}

\subsection{Study site}

The Rewalsar Lake is situated in the Mandi District of Himachal Pradesh, India (i.e., at northwest Himalaya), at $31^{\circ} 38^{\prime} \mathrm{N}$ latitude, $76^{\circ} 50^{\prime} \mathrm{E}$ longitude and an elevation of $1360 \mathrm{~m}$ above mean sea level (Fig. 1). It is $225 \mathrm{~m}$ long, $160 \mathrm{~m}$ wide, $6 \mathrm{~m}$ deep and having a catchment area of $1.17 \mathrm{~km}^{2}$. It is to the south of Main Boundary Thrust (MBT), and its geology comprises shale, calcareous segregation and quartzitic sandstone intercalated with siltstone [28]. Annual rainfall in the region is around $113.6 \mathrm{~cm}$, which is a main source of water for the lake, and instead the water may seepage from underground and surrounding rocks. The water inlets are situated toward the northern and western sides of the lake, whereas the water outlet is situated toward the eastern side. Besides, the Monastery (Tso Pema), Temple (Nyigma), Gurudwara (Rewalsar Sahib) and Rewalsar town also surround the lake. Owing to religious importance, the lake is considered as a main pilgrimage site for Buddhists, Sikhs and Hindus [28, 29].

\subsection{Methodology}

\subsubsection{Sampling procedure and analytical technique}

The trophic status of the Rewalsar Lake has been determined with the help of Carlson's index [15] and water samples collected at a time from different parts of the lake during summer season (Fig. 1). The samples were collected in sterilized polyethylene bottles of one liter size. The parameters like EC, pH, TDS, DO and salinity 
Fig. 1 Locations of water sampling sites in the Rewalsar Lake of northwest Himalaya (HP), India

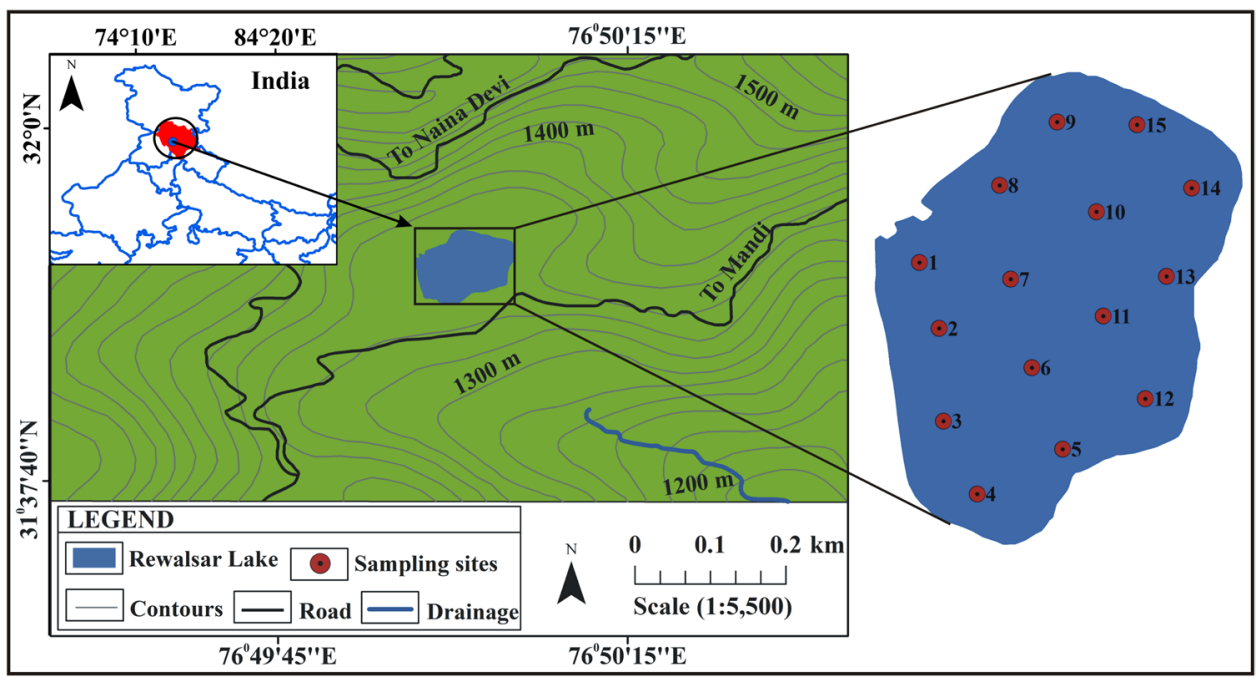

were determined in situ with a portable kit. The turbidity from the unfiltered water samples was observed with the help of turbidity meter. Instead, the $\mathrm{NH}_{4}{ }^{+}, \mathrm{NO}_{3}{ }^{-}$and $\mathrm{SO}_{4}{ }^{2-}$ were determined using ion chromatography instrument (Metrohm, 883 Basic IC Plus; Switzerland), according to the methodology as inferred by Kumar et al. [4]. The statistical software was used for the principal component and hierarchical cluster analysis.

\subsubsection{Secchi disk (SD) transparency}

The Secchi disk was $20 \mathrm{~cm}$ in diameter and lowered to the lake water at each water sampling site (Fig. 1). The exact depth of its visibility and invisibility was considered as SD transparency [5].

\subsubsection{Chlorophyll-a (Chl-a)}

The chlorophyll-a (Chl-a) was extracted by the acetone (HPLC grade) solution (90\%) prepared using Milli Q water. To determine it, $750 \mathrm{ml}$ lake water sample was filtered through Whatman glass fiber filter paper (GF/C; $47 \mathrm{~mm}$ ) and few seconds before the completion of filtration, 2-3 $\mathrm{ml} \mathrm{MgCO}{ }_{3}$ solution ( $1.0 \mathrm{~g} \mathrm{MgCO}_{3}$ and $100 \mathrm{ml}$ Milli $\mathrm{Q}$ water) was added. Filtrate along with filter paper was torn in a tissue grinder, and $3 \mathrm{ml}$ acetone solution was added [30]. The tissue grinder was run for $3 \mathrm{~min}$ at $500 \mathrm{rpm}$, and content was inverted in a centrifuge tube. Then, the total volume in centrifuge tube was fixed at $10 \mathrm{ml}$ by adding acetone solution. The tube was then centrifuged for $20 \mathrm{~m}$ at $3000 \mathrm{rpm}$ and thereafter the content was used for chlorophyll-a analysis with the instrument UV/Vis Spectrophotometer, which was calibrated using C5753-Spinach chlorophyll-a standard [5]. A reference sample of double distilled water was also prepared along with the lake samples. Concentration of chlorophyll-a ( $\mu \mathrm{g} \mathrm{L}^{-1}$ ) was calculated according to the formula: $C h l-a=\left[26.7(664 b-665 a) \times V_{1}\right] / V_{2} \times L[30]$.

\subsubsection{Total phosphorus (TP)}

The lake samples for the determination of the total phosphorus were digested according to the persulfate digestion and ascorbic acid method $[5,30]$.

2.2.4.1 Persulfate digestion method A $50 \mathrm{ml}$ lake sample was taken, and a drop of phenolphthalein indicator was added to test the acidic or basic nature of the sample solution. Thereafter, $0.4 \mathrm{~g}$ ammonium persulfate $\left[\left(\mathrm{NH}_{4}\right)_{2} \mathrm{~S}_{2} \mathrm{O}_{8}\right]$ and $1 \mathrm{ml}$ of $\mathrm{H}_{2} \mathrm{SO}_{4}$ solution were added to the sample and kept for half an hour on a hot plate. The volume of sample was reduced to $10 \mathrm{ml}$, which was cooled and further increased to $30 \mathrm{ml}$ by double distilled water. Then, the sample solution was autoclaved for half an hour and thereafter again cooled at room temperature. Finally, a $0.05 \mathrm{ml}$ phenolphthalein indicator and a few drops of sodium hydroxide $(\mathrm{NaOH})$ were added in the solution and further diluted to $100 \mathrm{ml}$ with double distilled water [30].

2.2.4.2 Ascorbic acid method This method comprises four solutions prepared with the chemicals of analytical reagent (AR) grade and double distilled water as: (1) a 500 $\mathrm{ml}$ solution of $5 \mathrm{~N} \mathrm{H}_{2} \mathrm{SO}_{4}$; (2) a $1.37 \mathrm{~g}$ antimony potassium tartrate $\left[\mathrm{K}(\mathrm{SbO}) \mathrm{C}_{4} \mathrm{H}_{4} \mathrm{O}_{6} \cdot{ }^{1} /{ }_{2} \mathrm{H}_{2} \mathrm{O}\right]$ solution having a final volume of $500 \mathrm{ml}$; (3) a $20 \mathrm{~g}$ ammonium molybdate $\left[\left(\mathrm{NH}_{4}\right)_{6} \mathrm{Mo}_{7} \mathrm{O}_{24} \cdot 4 \mathrm{H}_{2} \mathrm{O}\right]$ solution $(500 \mathrm{ml})$; and (4) a $1.76 \mathrm{~g}$ ascorbic acid $\left(\mathrm{C}_{6} \mathrm{H}_{8} \mathrm{O}_{6}\right)$ solution $(100 \mathrm{ml})$. Thereafter from the above four chemical solutions, 50, 5, 15 and $30 \mathrm{ml}$, respectively, were taken and mixed in a volumetric flask to make a combined chemical solution. Then, the lake samples prepared by the persulfate digestion method were mixed with the combined chemical solution in the ratio 
of 50:8 $\mathrm{ml}$. Thereafter, the samples were analyzed with the UV-Vis spectrophotometer at $880 \mathrm{~nm}$ absorbance and the total phosphorus concentrations thus determined $[5,30]$.

\subsubsection{Trophic state index (TSI)}

The TSI of the Rewalsar Lake was observed with Carlson's index that requires concentration of chlorophyll-a (Chl-a) and total phosphorus (TP) in $\mu \mathrm{g} \mathrm{L}^{-1}$ and the Secchi disk (SD) transparency in meter $(\mathrm{m})$. The following formulae were utilized to determine TSI as $[5,15]$ :

$\operatorname{TSI}(\mathrm{ChI}-\mathrm{a})=10[6-(2.04-0.68 \ln \mathrm{ChI}-\mathrm{a}) / \ln 2]$; $\mathrm{TSI}(\mathrm{TP})=10[6-\ln (48 / \mathrm{TP}) / \ln 2] ; \mathrm{TSI}(\mathrm{SD})=10[6-\ln (\mathrm{SD}) / \ln 2]$; and $\mathrm{TSI}($ avg. $)=\frac{\mathrm{TSI}(\mathrm{Chl}-a)+\mathrm{TSI}(\mathrm{TP})+\mathrm{TSI}(\mathrm{SD})}{3}$

\section{Results and discussion}

The results of physiochemical parameters of the Rewalsar Lake are shown in Fig. 2. The $\mathrm{pH}$ of the lake was found to be in a range of 7.25-7.46 (avg. 7.38 \pm 0.06 ) and within the permissible limit of the Bureau of Indian Standards (BIS) [31]. The $\mathrm{pH}$ indicates hydrogen ion concentration in water and a greater sum of such ions marks the water acidic, while the higher contribution of hydroxyl ions turns the water alkaline [32]. It is primarily a subsequent creation of carbonic acid $\left(\mathrm{H}_{2} \mathrm{CO}_{3}\right)$ and bicarbonate $\left(\mathrm{HCO}_{3}{ }^{-}\right)$. Most of the Himalayan lakes have been noticed alkaline in nature by several researchers in past decades [33]. The clarity of the Rewalsar Lake was known by quantifying turbidity, and its higher values in the range of 10.25-11.35 NTU (avg.10.84 $\pm 0.45 \mathrm{NTU}$ ) indicated the occurrence of algae, phytoplankton and organic color in water.

The electrical conductivity (EC) is a parameter to access ionic composition in the lake and was found to be 213-230
Fig. 2 Concentrations of different physiochemical parameters at the Rewalsar Lake. The values of all parameters $(\mathbf{a}-\mathbf{d})$ are in $\mathrm{mg} \mathrm{L}^{-1}$ and apart from, the $\mathrm{EC}$ is in $\mu \mathrm{S} / \mathrm{cm}$; turbidity as NTU; and SD in meter. The $\mathrm{pH}$, TSI(Chl-a), TSI(SD), TSI(TP) and TSI (avg.) are having numerical values
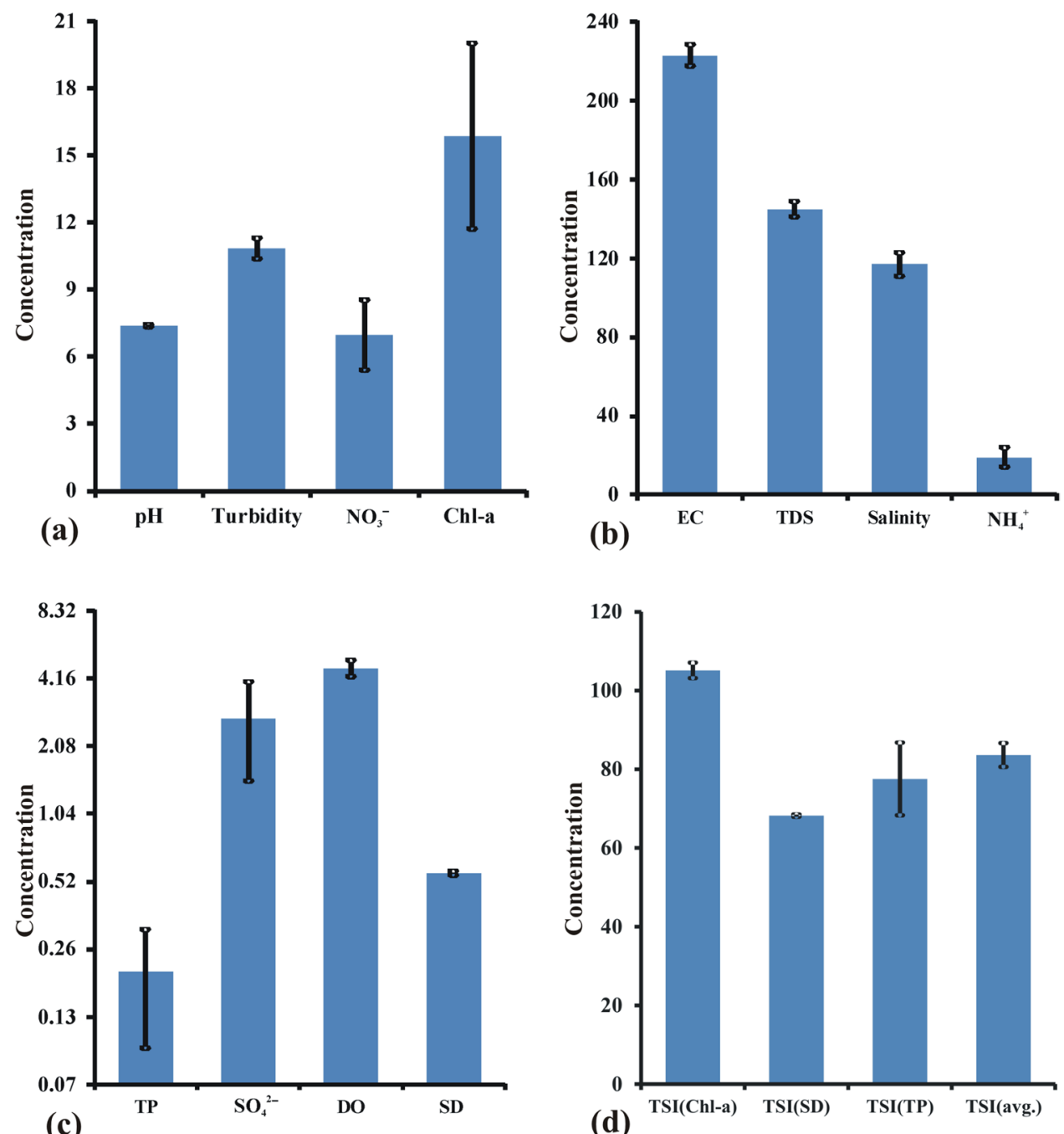
$\mu \mathrm{S} / \mathrm{cm}$ (avg. $222.7 \pm 5.34 \mu \mathrm{S} / \mathrm{cm}$ ), but within the permissible limit [31]. The nitrate $\left(\mathrm{NO}_{3}{ }^{-}\right)$content in a range of 5.23-11.52 $\mathrm{mg} \mathrm{L}^{-1}$ (avg. $6.97 \pm 1.56 \mathrm{mg} \mathrm{L}^{-1}$ ) and ammonium $\left(\mathrm{NH}_{4}^{+}\right.$) as $12.80-28.60 \mathrm{mg} \mathrm{L}^{-1}$ (avg. $18.93 \pm 5.02 \mathrm{mg}$ $\mathrm{L}^{-1}$ ) inferred the nutrient enrichment in the lake. Anthropogenic activities including use of nitrogenous fertilizers in the surrounding region may be the main source of $\mathrm{NO}_{3}{ }^{-}$and $\mathrm{NH}_{4}{ }^{+}$in the lake, apart from the natural process of nitrification and ammonification [2]. The concentration of $\mathrm{NO}_{3}{ }^{-}$more than permissible limit $\left(45 \mathrm{mg} \mathrm{L}^{-1}\right.$; BIS [31]) may cause health-related problems.

However, the Bhimtal, Sattal, Naukuchiatal and Nainital Lake are observed to have a higher concentration of $\mathrm{NO}_{3}{ }^{-}$, whereas the Renuka Lake is having less concentration as compared to the Rewalsar Lake [33]. The $\mathrm{NH}_{3}$ in the lake is harmful, whereas the $\mathrm{NH}_{4}{ }^{+}$is required for growth of the phytoplankton. The TDS in the Rewalsar Lake was noticed as $138-151 \mathrm{mg} \mathrm{L}^{-1}$ (avg. $144.7 \pm 3.99 \mathrm{mg} \mathrm{L}^{-1}$ ), whereas the salinity was found to be $107-126 \mathrm{mg} \mathrm{L}^{-1}$ (avg. $116.8 \pm 5.91$ $\mathrm{mg} \mathrm{L}^{-1}$ ). These were also within the permissible limit and infer the presence of organic and inorganic dissolved materials as well as salts content in the lake [34].

The chlorophyll-a can generally be available in all of the green plants and algae, which carry out photosynthesis. The Rewalsar Lake indicated its concentration in the range of $9.26-21.72 \mathrm{mg} \mathrm{L}^{-1}$ (avg. $15.85 \pm 4.16 \mathrm{mg} \mathrm{L}^{-1}$ ), whereas the total phosphorus was found to be $0.06-0.38 \mathrm{mg} \mathrm{L}^{-1}$ (avg. $0.21 \pm 0.11 \mathrm{mg} \mathrm{L}^{-1}$ ). The concentration of chlorophyll-a in the Rewalsar Lake was less than observed by Kumar et al. [5] from the Renuka Lake $\left(39.11 \mathrm{mg} \mathrm{L}^{-1}\right)$. The dissolved oxygen (DO) concentration less than $5 \mathrm{mg} \mathrm{L}^{-1}$ may create stress for aquatic lives and the present study indicated its average content $4.61 \pm 0.39 \mathrm{mg} \mathrm{L}^{-1}$, which is harmful for the survival of aquatic species as it may impact their certain metabolic activities $[35,36]$. The $\mathrm{SO}_{4}{ }^{2-}$ in the lake was found to be in the range of $1.15-5.24 \mathrm{mg} \mathrm{L}^{-1}$ (avg. $\left.2.74 \pm 1.29 \mathrm{mg} \mathrm{L}^{-1}\right)$, but within the permissible limit, i.e., $200 \mathrm{mg} \mathrm{L}^{-1}[31]$.
The $\mathrm{SO}_{4}{ }^{2-}$ may be produced from dissolution of carbonate minerals like gypsum, dolomite and calcite [37], and in addition, the uses of chemical fertilizers in the region also increase the $\mathrm{SO}_{4}{ }^{2-}$ content in the lake [2]. The $\mathrm{SO}_{4}{ }^{2-}$ in the Rewalsar Lake was observed much less than the Surinsar (11 $\left.\mathrm{mg} \mathrm{L}^{-1}\right)$ and Tsomoriri Lake $\left(88 \mathrm{mg} \mathrm{L}^{-1}\right)$, but more than the Sella $\left(0.11 \mathrm{mg} \mathrm{L}^{-1}\right)$ and Tso Kyo Lake $\left(0.14 \mathrm{mg} \mathrm{L}^{-1}\right)$ [33, 38]. The Secchi disk (SD) transparency indicated that the light penetration in the Rewalsar Lake is only 0.54-0.59 $\mathrm{m}$ (avg. $0.57 \pm 0.01 \mathrm{~m}$ ). The low SD transparency observed in the Rewalsar Lake may be due to abundance of algae, phytoplankton, macrophytes, suspended particles and color produced by the degradation of organic materials in the lake.

\subsection{Multivariate statistical analysis}

\subsubsection{Trophic classification}

Based on Carlson's index [15], the value of TSI(Chl-a) was found to be between 101.70 to 107.50 (avg. 105.12 \pm 1.97 ) and TSI(SD) from 67.62 to 68.93 (avg. $68.22 \pm 0.30$ ). On the other hand, the value of TSI(TP) was calculated 63.22-89.85 (avg. $77.53 \pm 9.22$ ). The average value of TSI for the Rewalsar Lake was thus observed in the range of 78.76-87.89 (avg. 83.62 \pm 3.09 ), which indicated that status of the Rewalsar Lake is hyper-eutrophic, according to the criteria as given in Table 1. However, the value of TSI for the Rewalsar Lake is more than other Himalayan lakes, viz. Renuka [5] and Mansar [22], which may be due to increasing anthropogenic activities causing more nutrient supply in this lake.

The factors governing productivity in the Rewalsar Lake were understood using a scatter plot defining comparison of TSI(Chl-a)-TSI(SD) toward $x$-axis and TSI(Chl-a)-TSI(TP) toward $y$-axis (Fig. 3) $[5,15]$. The locations of sampling points in the scatter plot are indicating that the "nutrients (TP) limiting large sized algae" is the regulating factor

Table 1 Criteria of classifying trophic state index (TSI) for the lakes [15]

\begin{tabular}{|c|c|c|c|}
\hline Sr. no. & TSI & Status of the lake & Detail description \\
\hline 1 & $<30$ & Oligotrophic & $\begin{array}{l}\text { The clear water and dissolved oxygen (DO) are present in the deepest layer "hypolimnion" throughout the } \\
\text { year }\end{array}$ \\
\hline 2 & $30-40$ & Oligotrophic & $\begin{array}{l}\text { The hypoliminion layer of the shallow lakes turned anoxic during summer; the deep lakes exhibit classical } \\
\text { oligotrophy }\end{array}$ \\
\hline 3 & $40-50$ & Mesotrophic & $\begin{array}{l}\text { The water has moderate clarity, and there is a probability for the hypoliminion layer to be turned anoxic } \\
\text { during summer }\end{array}$ \\
\hline 4 & $50-60$ & Eutrophic & $\begin{array}{l}\text { The transparency decreased, lower stage of eutrophy, hypolimnion turns anoxic during summer, pres- } \\
\text { ence of macrophytes and warm water fishes }\end{array}$ \\
\hline 5 & $60-70$ & Eutrophic & Dominance of blue green algae and excessive macrophytes \\
\hline 6 & $70-80$ & Hyper-eutrophic & Dense macrophytes and heavy algal bloom \\
\hline 7 & $>80$ & Hyper-eutrophic & Fishes die off during summer, algal scum, few macrophytes and fishes dominance \\
\hline
\end{tabular}




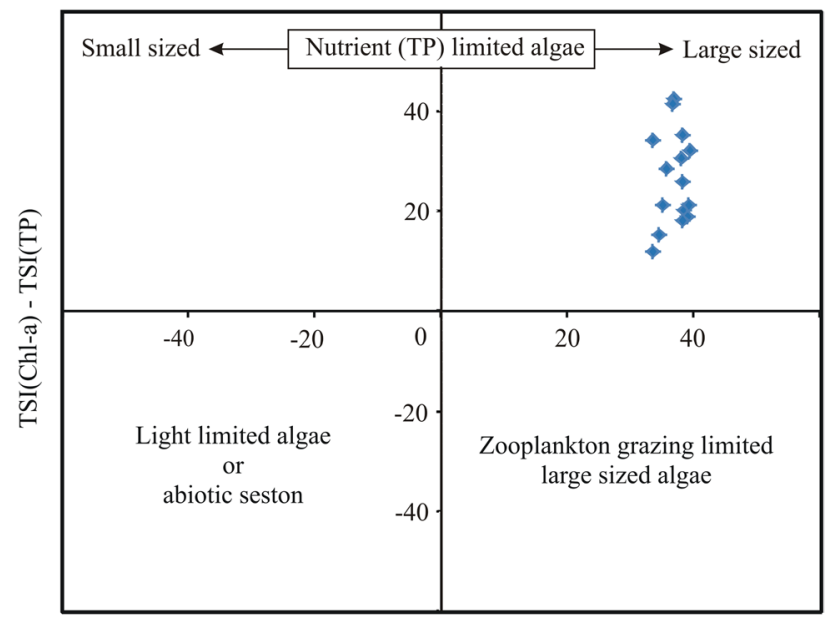

TSI(Chl-a) - TSI(SD)

Fig. 3 Main regulating factor for the algal growth in the Rewalsar Lake $[5,18]$

for the higher value of trophic state index at the Rewalsar Lake, which is therefore declared as hyper-eutrophic in status. If the total phosphorus concentration from the Rewalsar Lake is reduced, then the chlorophyll-a concentration will also be decreased and the visibility thus increased. The total phosphorus (TP) was also observed as a main regulating factor for the nutrient enrichment and growth of algae at the Whatcom (USA), Uluabat (Turkey), Poyang (China) and Renuka Lake (India) by Matthews et al. [39], Elmacy et al. [40], Liao et al. [41] and Kumar et al. [5], respectively. However, the increasing concentration of nitrogenous compounds should not be ignored as these may also impact algal growth in the Rewalsar Lake.

\subsubsection{Correlation coefficient}

The correlation coefficient $(r)$ has been considered to understand the relationships and sources of different parameters in the lake. The value of $r>0.5-0.79$ is considered as positive correlation and $r>0.8$ as strong positive correlation, and similarly $r>-0.5$ to -0.79 as negative correlation and $r>-0.8$ as strong negative correlation [2]. Table 2 indicates that the $\mathrm{EC}$ and $\mathrm{NH}_{4}{ }^{+}$are having positive correlation that suggests the direct impact of each other on their values, whereas other parameters like salinity- $\mathrm{pH}$, $\mathrm{SO}_{4}{ }^{2-}$ and DO- $\mathrm{NH}_{4}{ }^{+}$and TP are having negative correlations indicating their different sources. The significant level of correlation coefficient was known using $p$-value, which indicated the parameters shown in bold are statistically significant at $p>0.05$ (see Table 2).

\subsubsection{Principal component analysis (PCA)}

The principal component analysis elucidates the strength of correlations and variance in the data set of 12 different parameters of the Rewalsar Lake [42]. The bi-plots (Fig. 4a and b) were derived to understand distribution patterns and variance percent of different parameters, while the factor loading to evaluate dominant parameters in the three principal components (Table 3). The principal component 1 (PC1) marked $27.53 \%$ variance in the data set, while principal component 2 (PC2) as $17.48 \%$ (Fig. 4a). However, principal component 3 (PC3) indicated a 14.67\% variance (Fig. 4 b); thus, a total of $59.69 \%$ variance was observed through three principal components. An earlier study by Liu et al. [43] had inferred the value of factor loading in the range of $0.30-0.50$ as weak, $0.50-0.75$ moderate and $>0.75$ strong. The PC1 in the present study indicated moderate positive loadings for salinity $(0.74)$ and $D O(0.69)$

Table 2 Correlation coefficient between different parameters of the Rewalsar Lake

\begin{tabular}{|c|c|c|c|c|c|c|c|c|c|c|c|c|}
\hline & $\mathrm{PH}$ & TDS & $\mathrm{EC}$ & Salinity & DO & $\mathrm{NH}_{4}^{+}$ & $\mathrm{NO}_{3}^{-}$ & $\mathrm{SO}_{4}{ }^{2-}$ & Turbidity & SD & TP & Chl-a \\
\hline $\mathrm{pH}$ & 1 & & & & & & & & & & & \\
\hline TDS & 0.099 & 1 & & & & & & & & & & \\
\hline EC & -0.451 & 0.374 & 1 & & & & & & & & & \\
\hline Salinity & $-.586^{*}$ & -0.385 & -0.140 & 1 & & & & & & & & \\
\hline DO & -0.291 & -0.382 & -0.004 & 0.307 & 1 & & & & & & & \\
\hline $\mathrm{NH}_{4}^{+}$ & 0.050 & 0.460 & $0.533^{*}$ & -0.294 & -.507 & 1 & & & & & & \\
\hline $\mathrm{NO}_{3}^{-}$ & -0.069 & -0.292 & -0.304 & 0.263 & -0.034 & -0.358 & 1 & & & & & \\
\hline $\mathrm{SO}_{4}{ }^{2-}$ & 0.435 & 0.491 & -0.103 & $-.544^{*}$ & -0.252 & 0.201 & -0.233 & 1 & & & & \\
\hline Turbidity & 0.039 & 0.397 & 0.262 & -0.295 & -0.395 & 0.355 & 0.035 & 0.041 & 1 & & & \\
\hline SD & -0.124 & 0.091 & 0.066 & 0.322 & 0.197 & -0.125 & 0.454 & -0.157 & -0.107 & 1 & & \\
\hline TP & 0.176 & 0.177 & 0.008 & -0.194 & $-.571^{*}$ & -0.001 & 0.392 & 0.086 & -0.075 & 0.157 & 1 & \\
\hline $\mathrm{Chl}-\mathrm{a}$ & -0.026 & -0.077 & 0.364 & -0.312 & 0.431 & -0.282 & -0.053 & -0.290 & 0.114 & 0.140 & 0.030 & 1 \\
\hline
\end{tabular}

*Correlation is significant at $p>0.05$ (two-tailed test) 

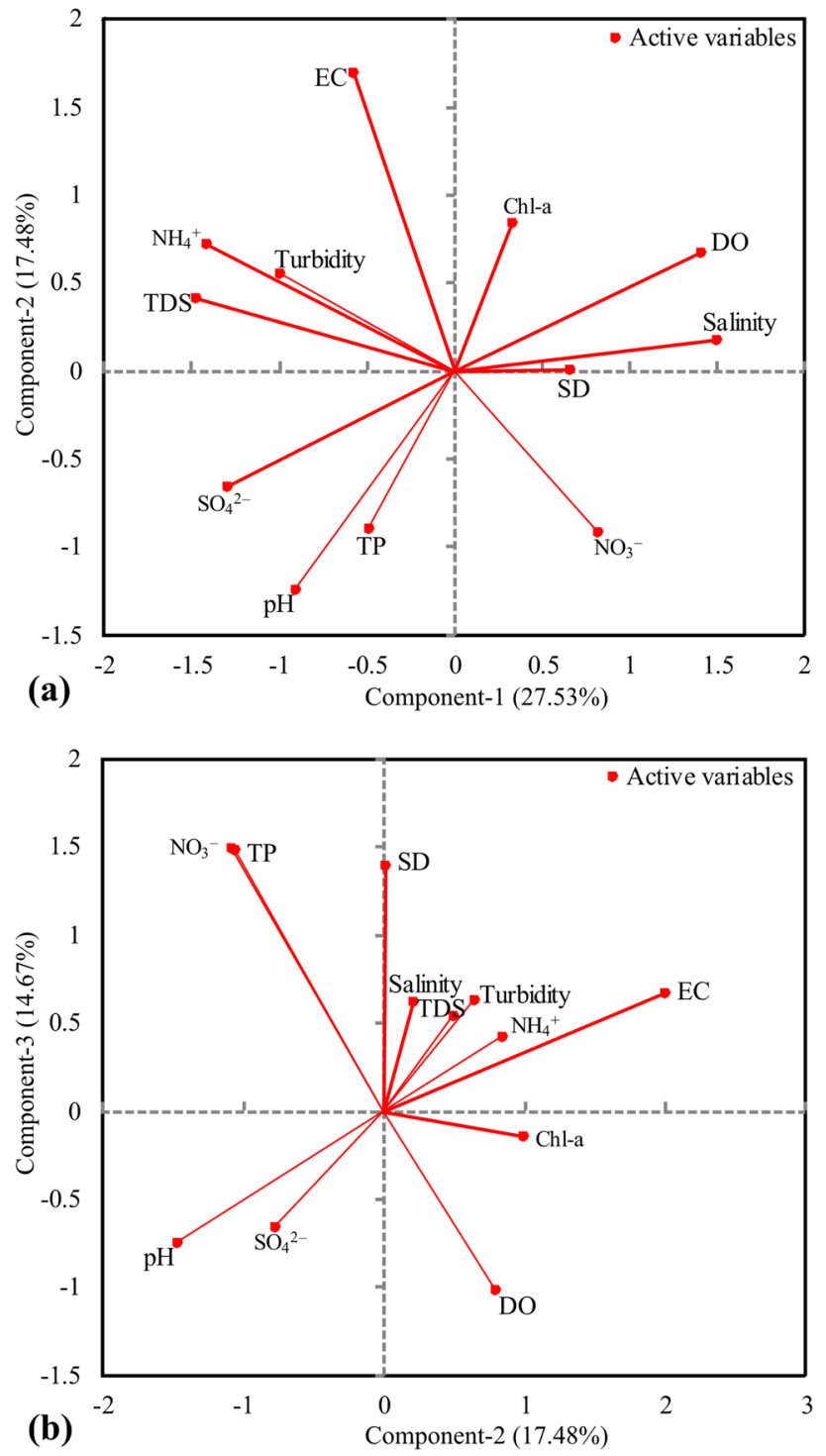

Fig. 4 Bi-plots indicating principal component analysis (PCA): a component 1 versus 2; $\mathbf{b}$ component 2 versus 3

and low in case of $\mathrm{NO}_{3}^{-}(0.40)$ and SD (0.33) (Table 3). It suggests the higher impact of catchment geology and lower of the anthropogenic activities that may be the use of nitrogenous fertilizers in the catchment and addition of other organic materials in the lake.

The PC2 inferred the strong positive loading in case of $\mathrm{EC}(0.83)$ and low by the $\mathrm{DO}(0.33), \mathrm{NH}_{4}{ }^{+}(0.35)$ and $\mathrm{Chl}-\mathrm{a}$ (0.41). The EC represents the ionic species movement contributed by the major ions generated from the surrounding rocks weathering as inferred in an earlier study at Rewalsar Lake by Gaury et al. [2]. Thereafter, the $\mathrm{DO}, \mathrm{NH}_{4}{ }^{+}$and $\mathrm{Chl}-\mathrm{a}$ are linked with the influence of anthropogenic activities. Similarly, PC3 showed moderate positive loadings for $\mathrm{NO}_{3}^{-}(0.62), \mathrm{TP}(0.62)$ and SD (0.58), thereby indicating the higher impact of agricultural runoff and other organic
Table 3 Factor loading for different parameters at the Rewalsar Lake

\begin{tabular}{llrrr}
\hline Sr. no. & Parameter & \multicolumn{1}{c}{ PC1 } & \multicolumn{1}{c}{ PC2 } & \multicolumn{1}{c}{ PC3 } \\
\hline 1 & $\mathrm{pH}$ & -0.44 & -0.61 & -0.31 \\
2 & $\mathrm{TDS}$ & -0.72 & 0.21 & 0.22 \\
3 & $\mathrm{EC}$ & -0.28 & 0.83 & 0.28 \\
4 & Salinity & 0.74 & 0.09 & 0.26 \\
5 & $\mathrm{DO}$ & 0.69 & 0.33 & -0.43 \\
6 & $\mathrm{NH}_{4}{ }^{+}$ & -0.70 & 0.35 & 0.18 \\
7 & $\mathrm{NO}_{3}{ }^{-}$ & 0.40 & -0.45 & 0.62 \\
8 & $\mathrm{SO}_{4}{ }^{2-}$ & -0.64 & -0.32 & -0.28 \\
9 & $\mathrm{Turbidity}^{-}$ & -0.49 & 0.27 & 0.26 \\
10 & $\mathrm{SD}$ & 0.33 & 0.01 & 0.58 \\
11 & $\mathrm{TP}_{12}$ & -0.24 & -0.44 & 0.62 \\
Eigenvalue & $\mathrm{Chl-a}$ & 0.16 & 0.41 & -0.06 \\
Variance \% & & 3.30 & 2.10 & 1.76 \\
Variance sum \% & & 27.53 & 17.48 & 14.67 \\
\hline
\end{tabular}

inputs in the lake (Table 3). The PC1 and PC2 have indicated a higher influence of natural factors followed by the anthropogenic activities and $\mathrm{PC} 3$ as the human activities. However, the main regulating factor for the higher trophic status of the Rewalsar Lake is the TP and instead may be the nitrogenous compounds to some extent, which all are the resultant products of anthropogenic activities to a greater extent rather than the natural sources.

\subsubsection{Hierarchical cluster analysis (HCA)}

The hierarchical cluster analysis is generally considered to know similarities among the samples groups. For the Rewalsar Lake, it was observed that the sampling sites are grouped under several clusters due to variations in the concentration of different parameters from one location to the other. The clusters $1,3,4,6,7,8$ and 9 classified as one sampling site each, i.e., 4, 15, 9, 7, 6, 1 and 8, respectively, whereas cluster 2 comprised 5 and 3 , cluster 5 covered 13 and 10 , cluster 10 indicated 11 and 2, and similarly, cluster 11 marked as 14 and 12 sampling sites. However, the whole groups can further be divided into three main clusters, which indicated coverage of 3,4 and 5 under cluster 1 , and 10, 13, 9 and 15 in cluster 2 , whereas $12,4,2,11,8$, 1,6 and 7 under cluster 3 (Fig. 5).

\section{Comparison with other lakes}

The present study is compared with other lakes of Indian Himalaya (Mansar, Surinsar, Tsomoriri, Tso Kar and Renuka) [5, 22, 33], lower Indian regions (Mullankere, 
Fig. 5 Hierarchical cluster analysis for different sampling sites at the Rewalsar Lake
Table 4 Trophic state index (TSI) indicating trophic status of different lakes in India and abroad

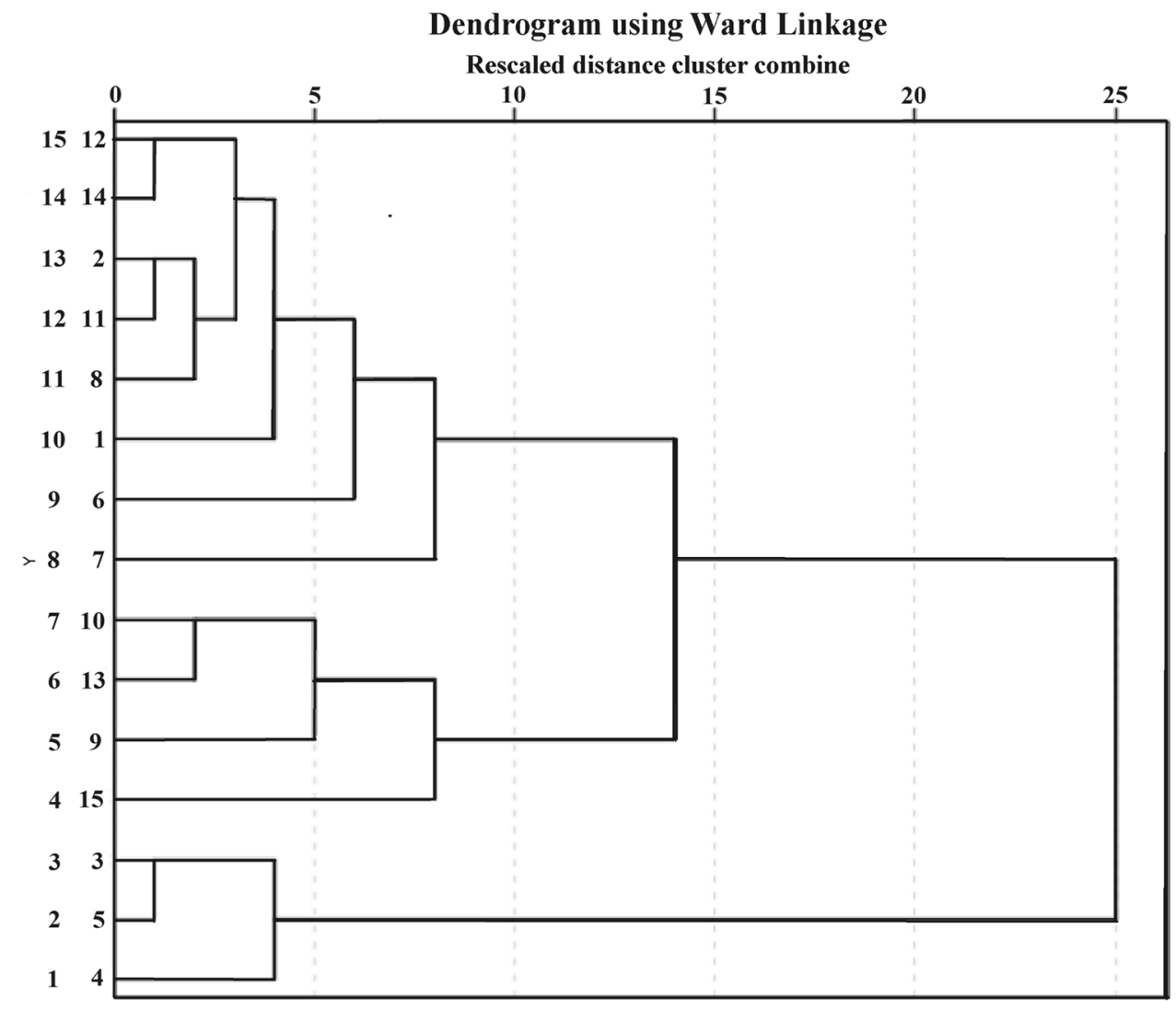

\begin{tabular}{llllll}
\hline Sr. no. & Name of the lake & Country & TSI & Trophic status & Reference \\
\hline 1 & Trichonis & Greece & 36.4 & Oligotrophic & Kehayias and Doulka [24] \\
2 & Naroch & Belarus & 38.9 & Oligotrophic & Adamovich et al. [47] \\
3 & Myastro & Belarus & 49 & Mesotrophic & \\
4 & Mansar & India & 67 & Eutrophic & Rai et al. [22] \\
5 & Surinsar & India & 61 & Eutrophic & Singh et al. [33] \\
6 & Tsomoriri & India & 53 & Eutrophic & \\
7 & Mullankere & India & 66.9 & Eutrophic & Barki and Singha [44] \\
8 & Akkamahadevi & India & 54.75 & Eutrophic & \\
9 & Krajwelek & Poland & 60.5 & Eutrophic & Jekatierynczuk-Rudczyk et al. [48] \\
10 & Kamendul & Poland & 56 & Eutrophic & \\
11 & Udziejek & Poland & 62 & Eutrophic & \\
12 & Dr. Joao Penido & Brazil & 53.5 & Eutrophic & Bucci et al. [25] \\
13 & Batorino & Belarus & 58.8 & Eutrophic & Adamovich et al. [47] \\
14 & Timsah & Egypt & 60 & Eutrophic & El-Serehy et al. [26] \\
15 & Tso Kar & India & 86 & Hyper-eutrophic & Singh et al. [33] \\
16 & Veli & India & 76 & Hyper-eutrophic & Sheela et al. [45] \\
17 & Akkulam & India & 80 & Hyper-eutrophic & \\
18 & Upper Lake & India & 71.6 & Hyper-eutrophic & Upadhyay et al. [46] \\
19 & Renuka & India & 79.16 & Hyper-eutrophic & Kumar et al. [5] \\
20 & Rewalsar & India & 83.62 & Hyper-eutrophic & Present study \\
\hline & & & & \\
\hline
\end{tabular}


Akkamahadevi, Veli, Akkulam and Upper Lake) [44-46] and abroad (Trichonis, Naroch, Myastro, Dr. Joao Penido, Krajwelek, Kamendul, Udziejek, Batorino and Timsah) $[24,25,47,48]$. It is inferred that most of the lakes are turned eutrophic and hyper-eutrophic in status (Table 4), which may be due to the increasing impact of anthropogenic activities [49]. The Trichonis and Naroch Lake (TSI: 36.4-38.9) may have fewer nutrients and face dissolved oxygen deficit during summer season $[24,47]$. The Myastro Lake of Greece is mesotrophic in status (TSI: 49), which is probably having moderate clarity and turns anoxic during summer [47].

Certain lakes situated in India and abroad are eutrophic due to nutrient enhancement, which results in dominance of algae and macrophytes. Such types of lakes generally have low transparency, and their deepest layers generally face a shortage of dissolved oxygen during summer. The Tso Kar, Veli, Akkulam, Renuka and Upper Lake are hypereutrophic in status (TSI: 71.6-86) [5, 33, 45, 46]. However, the present study has also indicated that the Rewalsar Lake is hyper-eutrophic (TSI: 83.62) due to nutrient enrichment. The lakes with TSI > 70-80 (Table 4) are labeled as highly nutritious and comprise higher algal bloom and dense macrophytes, whereas the lakes with TSI $>80$ generally develop algal scum and dominance of fishes, which get perished during summer as a result of higher temperature that fastens various lake processes $[35,36]$.

\section{Conclusion}

The present study has indicated contribution of chlorophyll-a (Chl-a), total phosphorus (TP) and Secchi disk (SD) transparency for defining trophic status of the Rewalsar Lake. The lake has been found to be hyper-eutrophic due to nutrient enrichment as a result of increasing anthropogenic activities like use of chemical fertilizers, instead of the natural factors like rocks weathering, ammonification and nitrification. The turbidity in the lake was found to be increased due to the occurrence of the phytoplankton and other suspended particles. The Secchi disk indicated low visibility in the lake that may be due to presence of organic color, algal particles and phytoplankton. The total phosphorus is observed as a main regulating factor for the higher trophic state index (TSI-83.62). However, the principal component analysis (PCA) has revealed a major contribution of natural sources on certain physiochemical parameters, but the regulating factors of the higher trophic status are found to be mainly linked with the anthropogenic activities. The hierarchical cluster (HCA) analysis has specified that the sampling sites of the lake are placed among various groups and showing spatial variability of different parameters. The Rewalsar Lake has lots of ecological and societal significances and therefore requires mitigation measures to control anthropogenic activities causing nutrients enrichment and maintain its natural scenario.

Acknowledgements The authors thank the management of Rewalsar Lake for providing a water boat for the samples collection. The anonymous reviewers are also acknowledged for their suggestions to improve the manuscript.

\section{Compliance with ethical standards}

Conflict of interest All the authors declare that they have no conflict of interest.

\section{References}

1. Iscen CF, Emiroglu O, Ilhan S, Arslan N, Yilmaz V, Ahiska S (2008) Application of multivariate statistical techniques in the assessment of surface water quality in Uluabat Lake, Turkey. Environ Monit Assess 144:269-276. https://doi.org/10.1007/s1066 1-007-9989-3

2. Gaury PK, Meena NK, Mahajan AK (2018) Hydrochemistry and water quality of Rewalsar Lake of Lesser Himalaya, Himachal Pradesh, India. Environ Monit Assess 190:84. https://doi. org/10.1007/s10661-017-6451-z

3. Singh SK, Singh P, Gautam SK (2016) Appraisal of urban lake water quality through numerical index, multivariate statistics and earth observation data sets. Int J Env Sci Tech 13:445-456. https://doi.org/10.1007/s13762-015-0850-x

4. Kumar P, Meena NK, Mahajan AK (2019) Major ion chemistry, catchment weathering and water quality of Renuka Lake, north-west Himalaya, India. Environ Earth Sci 78:319. https:// doi.org/10.1007/s12665-019-8315-z

5. Kumar P, Mahajan AK, Meena NK (2019) Evaluation of trophic status and its limiting factors in the Renuka Lake of Lesser Himalaya, India. Environ Monit Assess 191:105. https://doi. org/10.1007/s10661-019-7247-0

6. Kumar P, Kumar P (2019) Removal of cadmium (Cd-II) from aqueous solution using gas industry-based adsorbent. SN Appl Sci 1:365. https://doi.org/10.1007/s42452-019-0377-8

7. Kumar P, Mahajan AK, Kumar A (2019) Groundwater geochemical facie: implications of rock-water interaction at the Chamba city (HP), northwest Himalaya, India. Environ Sci Pol Res. https ://doi.org/10.1007/s11356-019-07078-7

8. Diwate P, Meena NK, Bhushan R, Pandita S, Chandana KR, Kumar $\mathrm{P}$ (2020) Sedimentation rate $\left({ }^{210} \mathrm{~Pb}\right.$ and $\left.{ }^{137} \mathrm{Cs}\right)$, grain size, organic matter and bathymetric studies in Renuka Lake, Himachal Pradesh, India. Himal Geol 41(1):51-62

9. Chuai X, Chen X, Yang L, Zeng J, Miao A, Zhao H (2012) Effects of climatic changes and anthropogenic activities on lake eutrophication in different eco-regions. Int J Environ Sci Technol 9:503514. https://doi.org/10.1007/s13762-012-0066-2

10. Zhang JL, Wang LJ, Zheng BH, Liu DF, Yang ZJ (2016) Eutrophication status of the Daning River within the Three Gorges Reservoir and its controlling factors before and after experimental impoundment. Environ Earth Sci 75:1182. https://doi. org/10.1007/s12665-016-5931-8

11. Ye $L$, Han $X Q, X u Y Y, C a i$ QH (2007) Spatial analysis for spring bloom and nutrient limitation in Xiangxi Bay of Three Gorges 
Reservoir. Environ Monit Assess 127:135-145. https://doi. org/10.1007/s10661-006-9267-9

12. Liu C, Kroeze C, Hoekstra AY, Gerbens-Leenes W (2012) Past and future trends in grey water footprints of anthropogenic nitrogen and phosphorus inputs to major world rivers. Ecol Indic 18:42-49. https://doi.org/10.1016/j.ecolind.2011.10.005

13. Jeppesen E, Kristensen $P$, Jensen JP, Sondergaard M, Mortensen E, Lauridsen T (1991) Recovery resilience following a reduction in external phosphorus loading of shallow, eutrophic Danish lakes: duration, regulating factors and methods for overcoming resilience. Mem Ist Ital Idrobiol 48:127-148

14. Whitworth KL, Baldwin DS, Kerr JL (2012) Drought, floods and water quality: drivers of a severe hypoxic black water event in a major river system (the southern Murray-Darling Basin, Australia). J Hydrol 450:190-198. https://doi.org/10.1016/j.jhydr ol.2012.04.057

15. Carlson RE (1977) A trophic state index for lakes. Limnol Oceanogr 22:361-369. https://doi.org/10.4319/lo.1977.22.2.0361

16. Papoutsa C, Akylas E, Hadjimitsis D (2014) Trophic State Index derivation through the remote sensing of Case-2 water bodies in the Mediterranean region. Cent Eur J Geosci 6:67-68. https ://doi.org/10.2478/s13533-012-0161-4

17. Kintu IM, Gidudu A, Letaru L (2019) Assessment of lake Victoria's trophic status using satellite-derived Secchi disk depth. 12th international conference of the African association of remote sensing and the environment. In: Wade S (ed) Earth observations and geospatial science in service of sustainable development goals. Southern Space Studies, Berlin, pp 79-87. https://doi.org/10.1007/978-3-030-16016-6-8

18. Carlson RE (1991) Expanding the trophic state concept to identify non-nutrient limited lakes and reservoirs. Enhancing the states's lake management programs, pp 59-71

19. Havens KE (2000) Using trophic state index (TSI) values to draw inferences regarding phytoplankton limiting factors and seston composition from routine water quality monitoring data. Korean J Limnol 33:187-196

20. Havens KE (1994) Seasonal and spatial variation in nutrient limitation in a shallow sub-tropical lake (Lake Okeechobee, Florida) as evidenced by trophic state index deviations. Arch Hydrobiol 131:39-53

21. Edmondson WT (1980) Secchi disk and chlorophyll. Limnol Oceanogr 25:378-379

22. Rai SP, Kumar V, Singh O, Kumar B, Jain A (2001) Limnological study of the Mansar Lake of District Udhampur, J\&K. Final project report. NIH WHRC, Jammu cant

23. Shuhaimi-Othman M, Lim EC, Mushrifah I (2007) Water quality changes in Chini Lake, Pahang, West Malaysia. Environ Monit Assess 131:279-292. https://doi.org/10.1007/s1066 1-006-9475-3

24. Kehayias G, Doulka E (2014) Trophic state evaluation of a large Mediterranean lake utilizing abiotic and biotic elements. J Environ Prot 5:17. https://doi.org/10.4236/jep.2014.51003

25. Bucci MMHS, Delgado FEDF, Oliveira LFCD (2015) Water quality and trophic state of a tropical urban reservoir for drinking water supply (Juiz de Fora, Brazil). Lake Reserv Manag 31:134144. https://doi.org/10.1080/10402381.2015.1029151

26. El-Serehy HA, Abdallah HS, Al-Misned FA, Al-Farraj SA, Al-Rasheid KA (2018) Assessing water quality and classifying trophic status for scientifically based managing the water resources of the Lake Timsah, the lake with salinity stratification along the Suez Canal. Saudi J Biol Sci 25:1247-1256. https://doi. org/10.1016/j.sjbs.2018.05.022

27. Okmen G, Arslan A (2019) The effects of environmental conditions on growths of halophilic archaea isolated from Lake Tuz. Int J Env Sci Tech 16:5155-5162. https://doi.org/10.1007/ s13762-018-1971-9
28. Sarkar S, Prakasam M, Banergi US, Bhushan R, Gaury PK, Meena NK (2016) Rapid sedimentation history of Rewalsar Lake, Lesser Himalaya, India during the last fifty years-estimated using ${ }^{137} \mathrm{Cs}$ and ${ }^{210} \mathrm{~Pb}$ dating techniques: a comparative study with other north-western Himalayan lakes. Himal Geol 37(1):1-7

29. Jindal R, Thakur RK (2013) Diurnal variations of plankton diversity and physico-chemical characteristics of Rewalsar Wetland, Himachal Pradesh. India. Recent Res Sci Technol 5(3):04-09

30. APHA (2012). Standard method for the examination of water and wastewater. $22^{\text {nd }}$ ed. Washington DC (USA), ISBN-9780875530139

31. BIS (2012) Drinking Water Specification. 2nd revision, Bureau of Indian Standards, New Delhi, India

32. Isa NM, Aris AZ, Sulaiman WNAW (2012) Extent and severity of groundwater contamination based on hydrochemistry mechanism of sandy tropical coastal aquifer. Sci Total Environ 438:414-425. https://doi.org/10.1016/j.scitotenv.2012.08.069

33. Singh O, Rai SP, Kumar V, Sharma MK. Choubey VK (2008) Water quality and Eutrophication status of some lakes of the western Himalayan region (India). Proceeding of Taal-2007: The 12th world lake conference, pp 286-291

34. Huo S, Ma C, Xi B, Su J, He Z, Li X (2015) Establishing water quality reference conditions for nutrients, chlorophyll a and Secchi depth for 7 typical lakes in arid and semiarid ecoregion, China. Environ Earth Sci 73:4739-4748. https://doi. org/10.1007/s12665-014-3760-1

35. Urbina MA, Forster ME, Glover CN (2011) Leap of faith: voluntary emersion behaviour and physiological adaptations to aerial exposure in a non-aestivating freshwater fish in response to aquatic hypoxia. Physiol Behav 103:240-247. https://doi. org/10.1016/j.physbeh.2011.02.009

36. Small K, Kopf RK, Watts RJ, Howitt J (2014) Hypoxia, black water and fish kills: experimental lethal oxygen thresholds in juvenile predatory lowland river fishes. PLOS ONE 9:e94524. https://doi.org/10.1371/journal.pone.0094524

37. Zhu L, Ju J, Wang Y, Xie M, Wang J, Peng P, Zhen X, Lin X (2010) Composition, spatial distribution, and environmental significance of water ions in Pumayum Co catchment, southern Tibet. J Geogr Sci 20:109-120. https://doi.org/10.1007/s1144 2-010-0109-x

38. Deka JP, Tayeng G, Singh S, Hoque RR, Prakash A, Kumar M (2015) Source and seasonal variation in the major ion chemistry of two eastern Himalayan high altitude lakes, India. Arab J Geosci 8:10597-10610. https://doi.org/10.1007/s1251 7-015-1964-7

39. Matthews R, Hilles M, Pelletier G (2002) Determining trophic state in Lake Whatcom, Washington (USA), a soft water lake exhibiting seasonal nitrogen limitation. Hydrobiologia 468:107-121. https://doi.org/10.1023/A:1015288519122

40. Elmaci A, Ozengin N, Teksoy A, Topac FO, Baskaya HS (2009) Evaluation of trophic state of lake Uluabat, Turkey. J Env Biol 30:757

41. Liao M, Yu G, Guo Y (2017) Eutrophication in Poyang Lake (eastern China) over the last 300 years in response to changes in climate and lake biomass. PLoS ONE 12:e0169319. https:// doi.org/10.1371/journal.pone.0169319

42. Sivasankar V, Gomathi R (2011) Fluoride and other quality parameters in the groundwater samples of Pettaivaithalai and Kulithalai areas of Tamil Nadu, Southern India. Water Qual Expo Health 1:123-134. https://doi.org/10.1007/s1240 3-009-0008-5

43. Liu CW, Lin KH, Kuo YM (2003) Application of factor analysis in the assessment of groundwater quality in a Blackfoot disease area in Taiwan. Sci Total Environ 313(1-3):77-89. https://doi. org/10.1016/S0048-9697(02)00683-6 
44. Barki DN, Singa P (2014) Assessment of trophic state of lakes in terms of Carlson's trophic state index. Int J Innov Res Sci Engin Tech 3:14297-14302

45. Sheela AM, Letha J, Joseph S (2011) Environmental status of a tropical lake system. Environ Monit Assess 180:427-449. https ://doi.org/10.1007/s10661-010-1797-5

46. Upadhyay R, Pandey AK, Upadhyay SK, Bassin JK, Misra SM (2012) Limno-chemistry and nutrient dynamics in Upper Lake, Bhopal, India. Environ Monit Assess 184:7065-7077. https:// doi.org/10.1007/s10661-011-2480-1

47. Adamovich BV, Zhukova TV, Mikheeva TM, Kovalevskaya RZ, Lukyanova EV (2016) Long-term variations of the trophic state index in the Narochanskie lakes and its relation with the major hydro-ecological parameters. Water Resour 43:809-817. https ://doi.org/10.1134/S009780781605002x
48. Jekatierynczuk-Rudczyk E, Zielinski P, Grabowska M, EjsmontKarabin J, Karpowicz M, Wiecko A (2014) The trophic status of Suwalki Landscape Park lakes based on selected parameters (NE Poland). Environ Monit Assess 186(8):5101-5121. https:// doi.org/10.1007/s10661-014-3763-0

49. Kumar P, Meena NK, Mahajan AK (2019) The heavy metal contamination history during ca 1839-2003 AD from Renuka Lake of Lesser Himalaya, Himachal Pradesh, India. Environ Earth Sci 78:549. https://doi.org/10.1007/s12665-019-8519-2

Publisher's Note Springer Nature remains neutral with regard to jurisdictional claims in published maps and institutional affiliations. 